\title{
Continous surveillance of bloodstream infections across departments at a Danish University Hospital
}

\author{
RA Leth
}

From International Conference on Prevention \& Infection Control (ICPIC 2011)

Geneva, Switzerland. 29 June - 2 July 2011

\section{Introduction / objectives}

The rate of bloodstream infections has been monitored monthly since 2004 at Aarhus University Hospital, Skejby. The hospital is a tertiary referral hospital with 400 beds specialising in paediatrics, gynaecology \& obstetrics, urology, thoracic and vascular surgery, renal medicine, cardiology, infectious diseases and intensive care.

The aim of this study was to identify variations in bloodstream infection rates across departments.

\section{Methods}

Monthly all patients with positive blood cultures are monitored concerning true infection or contamination and if the infection is community-or hospital/healthcare-acquired. The bloodstream infection rates are presented as number of episodes per 1000 beddays. The infection rates are sent to each department quarterly followed by staff-meetings. To identify trends in bloodstream infection rates we also perform six-month moving averages.

\section{Results}

In the years 2007 - 2010 the total bloodstream infection rates for the hospital were 3.0, 3.1, 2.9, and 2.6 episodes per 1000 beddays. Hospital-acquired infections accounted for 2.2, 2.0, 2.0, and 2.0 episodes per 1000 bed-days. There were great differences in hospitalacquired bloodstream infection rates across departments ranging from 0.5 episodes per 1000 beddays in gynaecology \& obstetrics to 5.3 episodes per 1000 beddays in urology in 2010.

Department of Clinical Micorbiology, Aarhus University Hospital, Skejby, Aarhus N, Denmark

\section{Conclusion}

The overall rate of hospital-acquired bloodstream infections has remained at the same level in the past four years at our hospital. However, some departments have a high rate constituting a continuous challenge for improvement.

\section{Disclosure of interest}

None declared.

Published: 29 June 2011

doi:10.1186/1753-6561-5-S6-P64

Cite this article as: Leth: Continous surveillance of bloodstream

infections across departments at a Danish University Hospital. BMC Proceedings 2011 5(Suppl 6):P64.
Submit your next manuscript to BioMed Central and take full advantage of:

- Convenient online submission

- Thorough peer review

- No space constraints or color figure charges

- Immediate publication on acceptance

- Inclusion in PubMed, CAS, Scopus and Google Scholar

- Research which is freely available for redistribution

\section{() Biomed Central}

\section{Biomed Central}

